\title{
Ethylene Formation during Ripening of Kiwifruit
}

\author{
Hiroshi Hyodo, Saeko Aizawa and Shinichi Ao \\ Department of Horticulture, Faculty of Agriculture, \\ Shizuoka University, Ohya, Shizuoka 422
}

\begin{abstract}
Summary
Kiwifruits (Actinidia chinensis Planch. cv. Hayward) began to produce ethylene at an increasing rate (exponentially) at $21^{\circ} \mathrm{C}$ after reaching the threshold level of $0.1 \mu \mathrm{kg}^{-1} \mathrm{~h}^{-1}$. The high rate of ethylene production is associated with fruit ripening. The time required for the fruits to reach the threshold level became much shorter and the wide range of variation in the time became less after fruits were stored for 4 months and longer at $2^{\circ} \mathrm{C}$. Both 1-aminocyclopropane-1-carboxylic acid (ACC) and N-malonyl-ACC (MACC) levels increased in proportion to the rate of ethylene production in the range higher than $0.2 \mathrm{nmolg}^{-1} \mathrm{~h}^{-1}$, below which both ACC and MACC levels remained almost constant. Ethylene-forming enzyme (EFE) activity increased in parallel with the rate of ethylene production, which may indicate that EFE activity regulates ethylene production in the fruit tissue as well as the step of ACC formation.
\end{abstract}

\section{Introduction}

Kiwifruit is a climacteric fruit which shows a rise in ethylene production accompanied by an increase in respiration during ripening ( 3 , $8,9)$. The rise in ethylene production is followed by a decrease in flesh firmness. In a previous paper we reported that ethylene was produced at an increasing rate after exceeding a threshold level of $0.1 \mu \mathrm{kg}^{-1} \mathrm{~h}^{-1}$, that the increased rate of ethylene production was paralleled by the increased internal ethylene concentration in the fruit, and that ethylene biosynthesis in the kiwifruit may proceed along the methionine and 1-aminocyclopropane-1-carboxylic acid (ACC) pathway (3).

In the present study we investigated the changes in increasing patterns of ethylene production by individual kiwifruits after storage for various periods at a low temperature. We also studied the changes in ACC and Nmalonyl-ACC (MACC) contents and the development of ethylene-forming enzyme (EFE) activity in relation to the increase in the rate of ethylene production.

\footnotetext{
1 Received for publication December 17, 1986.
}

\section{Materials and Methods}

Kiwifruits (Actinidia chinensis Planch. cv. Hayward) were harvested 7 November 1984. in Shizuoka at full maturity. They were stored at $2^{\circ} \mathrm{C}$ under high relative humidity until used. For determination of ethylene production by individual fruits, fruits were. placed in 1.22-liter glass jars and sealed with plastic covers having one sampling port with a silicon rubber stopper. After $3 \mathrm{~h}$, the head-space gas in the jars was sampled and assayed for ethylene as described elsewhere (3). The rate of ethylene production was measured every day at $21^{\circ} \mathrm{C}$.

At various stages of ethylene production, the fruits were analyzed for ACC and MACC and assayed for EFE activity. Flesh tissue was homogenized with 10 times its volume $(\mathrm{v} / \mathrm{w})$ of $80 \%$ ethanol in a blender for $2 \mathrm{~min}$. The homogenate was centrifuged at $8,000 \times$ $g$ for $15 \mathrm{~min}$ at $2^{\circ} \mathrm{C}$. The supernatant was concentrated to dryness in vacuo at $45^{\circ} \mathrm{C}$ in a rotary evaporator. The residue was taken up in $5 \mathrm{ml}$ of water, and an aliquot of 0.5 $\mathrm{ml}$ was assayed for ACC by the method described by Lizada and Yang(7). MACC in the water extract was hydrolyzed in $2 \mathrm{~N} \mathrm{HCl}$ at $100^{\circ} \mathrm{C}$ for $3 \mathrm{~h}$. After hydrolysis the solu- 
ruon was neutralized with $2 \mathrm{~N} \mathrm{NaOH}$ and centrifuged at $3,000 \times g$ for $10 \mathrm{~min}$, and the supernatant was determined for total ACC content. The difference in the amount of ACC after and before acid hydrolysis was taken as that of MACC. ACC and MACC in the fruit extract were identified by paper chromatography.

EFE activity was assayed in vivo with flesh tissue in the presence of $1 \mathrm{mM}$ ACC. Ten discs $(9 \times 2 \mathrm{~mm})$ prepared from flesh tissue were placed in a $50-\mathrm{ml}$ Erlenmeyer flask containing $6 \mathrm{ml}$ of $10 \mathrm{mM}$ phosphate buffer, $\mathrm{pH}$ 6. 0 , containing $1 \mathrm{mM}$ ACC. The flasks were sealed with rubber serum caps and shaken at 120 strokes per min for $1 \mathrm{~h}$ at $24^{\circ} \mathrm{C}$. The head-space gas in the flasks was sampled and assayed for ethylene by gas chromatography.

\section{Results and Discussion}

The rate of ethylene production was measured at $21^{\circ} \mathrm{C}$ for individual fruits immediately after harvest and during storage for 4,6 and 9 months at $2^{\circ} \mathrm{C}$. In every experiment each

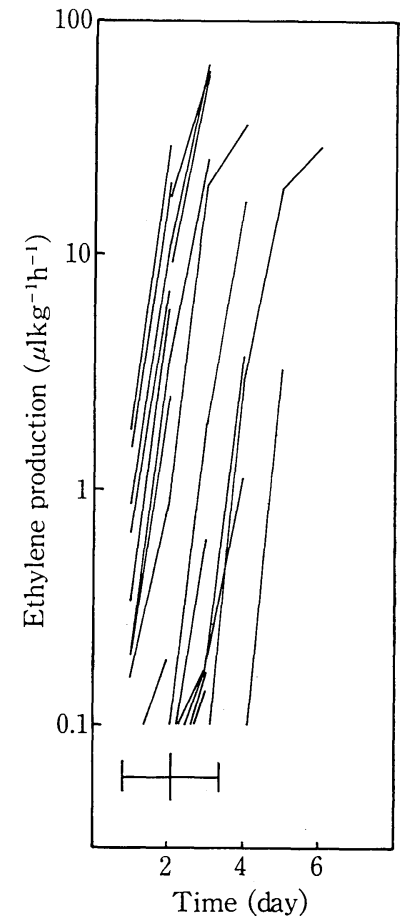

Fig. 1. Time course of ethylene production by single fruits measured at $21^{\circ} \mathrm{C}$ after storage at $2^{\circ} \mathrm{C}$ for 6 months. fruit began to produce ethylene at an increasing rate after reaching the rate higher than $0.1 \mu \mathrm{kg}^{-1} \mathrm{~h}^{-1}$, which was considered to be the threshold level for kiwifruit(3). Fig.1 shows the increasing patterns of ethylene production by single fruits which had been stored for 6 months at $2^{\circ} \mathrm{C}$ before they were measured at $21^{\circ} \mathrm{C}$. Rates of ethylene production less than $0.1 \mu \mathrm{kg}^{-1} \mathrm{~h}^{-1}$ are not illustrated in the figure. Some fruits rapidly reached a level much higher than $0.1 u \mathrm{lkg}^{-1} \mathrm{~h}^{-1}$ on transfer to the higher temperature at $21^{\circ} \mathrm{C}$ from the storage room at $2^{\circ} \mathrm{C}$. The mean time and its standard deviation for exceeding the limit rate of $0.1 \mu \mathrm{lkg}^{-1} \mathrm{~h}^{-1}$ were $2.1 \pm 1.3$ days $(n=19)$. The values for fruits measured from 1 week after harvest in November were $15.9 \pm 12.1$ days $(n=19)$ (3). Fig. 2 shows the changes in mean times and standard deviations for fruits to exceed the threshold level when measured after harvest and during storage for 4,6 and 9 months at $2^{\circ} \mathrm{C}$. After storage for 4 months and longer at $2^{\circ} \mathrm{C}$, the time required to reach the increased rate became much shorter and the previous wide range of variation became less. It appears that exposure to a low temperature $\left(2^{\circ} \mathrm{C}\right)$ or chilling stress may advance the onset of ethy-

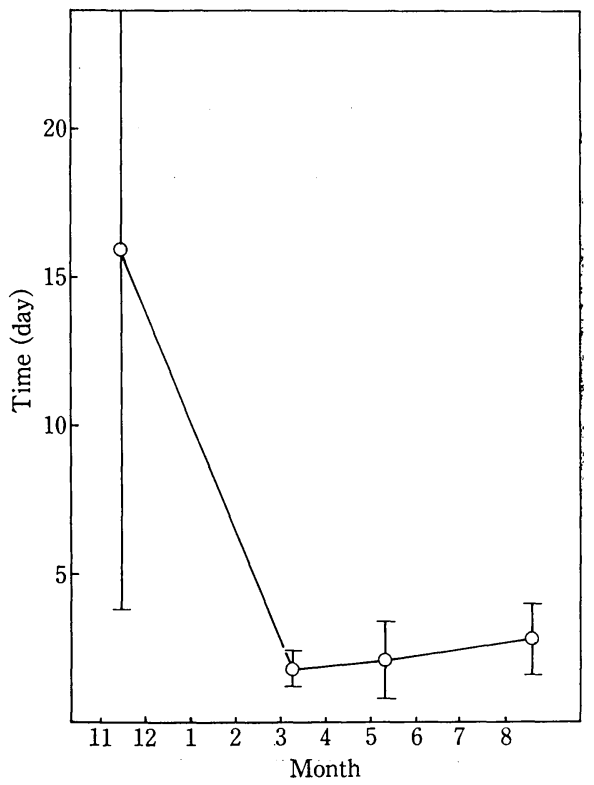

Fig. 2. The mean times and standard deviations for fruits to exceed the threshold level after harvest and storage at $2^{\circ} \mathrm{C}$ for various periods. 
lene production at a greater rate in the fruit when transferred to a higher temperature $\left(21^{\circ} \mathrm{C}\right)$. In cucumber fruit, chilling stress accelerates the induction of ACC synthase and the formation of ACC on transfer to a higher temperature, thus causing a high rate of ethylene paoruction(10).

At various stages of ethylene production ACC and MACC contents were assayed in the flesh tissue (Fig. 3). Before the rate of ethylene production reached about 0.2 $\mathrm{nmolg}{ }^{-1} \mathrm{~h}^{-1}\left(4.8 \mu \mathrm{kg}^{-1} \mathrm{~h}^{-1}\right)$, the ACC level remained constant at $0.6 \mathrm{nmolg}^{-1}$. In the range higher than $0.2 \mathrm{nmolg}^{-1} \mathrm{~h}^{-1}$ of the rate of ethylene production, ACC content rose progressively with the increasing rate (log $\mathrm{Y}=0.084+0.514 \log \mathrm{X}, \mathrm{r}=0.716$ ). The level of MACC was found to be much higher than that of ACC. The levels of MACC at the

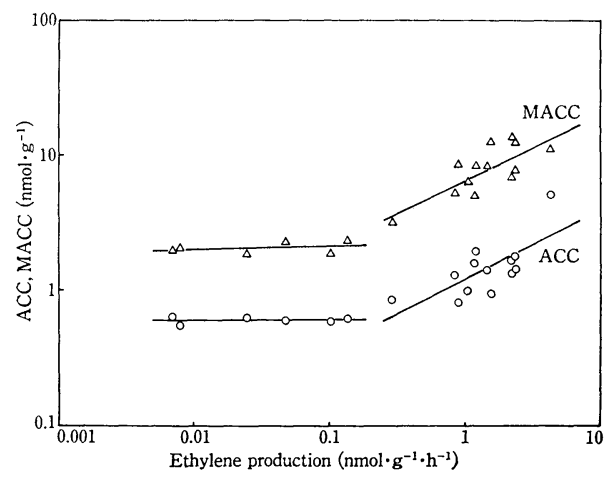

Fig. 3. Relationship between rate of ethylene production by the fruits and ACC and MACC contents of the flesh tissue.

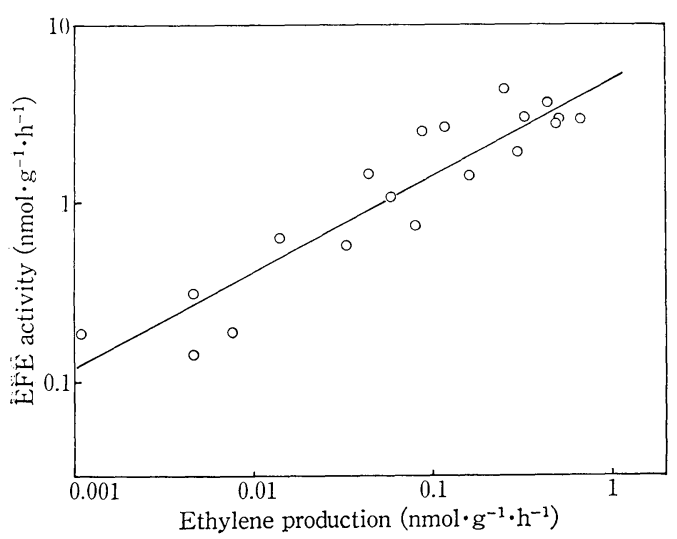

Fig. 4. Relationship between rate of ethylene production by the fruits and EFE activity in the flesh tissue. different stages of ethylene production showed the same tendency as those of ACC, i. e. until the rate of ethylene production reached $0.2 \mathrm{nmolg}^{-1} \mathrm{~h}^{-1}$, the level of MACC remained almost constant at $2 \mathrm{nmolg}^{-1}$ and in the range exceeding $0.2 \mathrm{nmolg}^{-1} \mathrm{~h}^{-1}$, MACC content increased in parallel with that of ACC $(\log \mathrm{Y}=0.816+0.4861 \log \mathrm{X}, \mathrm{r}=$ 0.773 ), being more than 5 times higher than that of ACC (Fig. 3). The fact that the ACC level increased in proportion to the rate of ethylene production at the higher rates may indicate that the rise in ACC is responsible for the increase in the rate of ethylene production. It is interesting that the level of MACC was much higher than that of ACC throughout the range of ethylene production, which suggests that ACCmalonyltransferase activity $(5,6)$ is high enough in either unripe or ripe kiwifruit to convert ACC to the malonyl derivative (MACC).

EFE activity in the flesh tissue was assayed for the fruits producing ethylene at different rates. There was a close relationship(Fig. 4) between EFE acticity and the rate of ethylene production by each fruit $(r=0.927)$, which may indicate that EFE activity is a limiting step regulating ethylene formation in the kiwifruit. It has been shown that EFE activity increases with the rise in ethylene production where ethylene is considered to be responsible for the induction and development of $\operatorname{EFE}(1,2)$.

We reported previously that ethylene biosynthesis in the kiwifruit may proceed along the methionine and ACC pathway(3). The present data support the view that ACC may act as an intermediate in ethylene biosynthesis and EFE may play an important role in regulating ethylene biosynthesis in the kiwifruit. We also reported that in the wounded mesocarp tissue of winter squash fruit, ACC synthase and EFE were markedly induced in response to wounding and a large amount of ACC was formed in the wounded tissue as a result(4). The great difference between the amount of ACC in ripe kiwifruit and in the wounded mesocarp tissue of winter squash may be due to the much higher activ- 
ity of ACC synthase found in the latter tissue.

\section{Literature Cited}

1. Bufler, G. 1986. Ethylene-promoted conversion of 1-aminocyclopropane-1-carboxylic acid to ethylene in peel of apple at various stages of fruit development. Plant Physiol. $80: 539-543$.

2. Hoffman, N.E. and S. F. Yang. 1983. Enhancement of wound-induced ethylene synthesis by ethylene treatment in preclimacteric cantaloupe. Plant Physiol. $69: 317-322$.

3. Hyodo, H. and R. Fukasawa. 1985. Ethylene production in kiwifruit. J. Japan. Soc. Hort. Sci. $54: 209-215$.

4. HYODO, H., K. TANAKA and J. YoSHISAKA. 1985. Induction of 1-aminocyclopropane-1carboxylic acid synthase in wounded mesocarp tissue of winter squash fruit and the effects of ethylene. Plant Cell Physiol. 26 : $161-167$.

5. Kionka, C. and N. Amrhein. 1984. The en- zymatic malonylation of 1-aminocyclopropane-1-carboxylic acid in homogenates of mung-bean hypocotyls. Planta $162: 226-235$.

6. LIU, Y., L. Y. SU and S. F. YANG. 1985.

Ethylene promotes the capability to malonate 1-aminocyclopropane-1-carboxylic acid and D-amino acids in preclimacteric tomato fruits. Plant Physiol. $77: 891-895$.

7. LIZADA, C. C. and S. F. YANG. 1979. A simple and sensitive assay for 1-aminocyclopropane-1-carboxylic acid. Anal. Biochem. $100: 140-145$.

8. LuH, B. S. and Z. WANG. $1984 . \quad$ Kiwifruit. Adv. Food Res. 29 : 279-309.

9. Pratt, H. K. and M. S. Reid. 1974. Chinese gooseberry : seasonal patterns in fruit growth and maturation, ripening, respiration and the role of ethylene. J. Sci. Food. Agr. $25: 747-757$.

10. WANG, C. Y. and D. O. AdAms. 1982. Chilling-induced ethylene production in cucumbers (Cucumis sativus L.) Plant Physiol. $69: 424-427$.

\section{キウイフルーツ追熟中のエチレン生成の増大 \\ 兵藤 宏・相沢彩恵子・青 真一 \\ 静岡大学農学部 422 静岡市大谷}

\begin{abstract}
摘
キウイフルーツ (Actinidia chinensis Planch. cv.

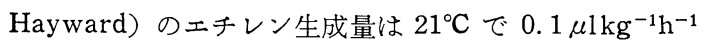
の限界值を越えた後急激（指数関数的）に増大した. 顕 著なエチンン生成は果実の追熟と密接な関連を有してい る. 収檴直後の果実では $0.1 \mu 1 \mathrm{~kg}^{-1} \mathrm{~h}^{-1}$ の限界檤を越す のにかなりの時間を必要とし，また個体間の差異がかな りみられたが (15.9土12.1日), 果実を低温下 $\left(2^{\circ} \mathrm{C}\right)$ で 貯蔵することにより，常温 $\left(21^{\circ} \mathrm{C}\right)$ に移した後のエチレ ン生成はかなり早まり，個体間のばらつきも小さくなっ た（6ケ月貯蔵後， $2.1 \pm 1.3$ 日). キゥイフルーツでエ チレン生合成の中間体とみなされる 1-アミノシクロプ ロパソー1-カルボン酸 (ACC) および N-マロニル-ACC
\end{abstract}

\section{要}

(MACC) の果実中の含量は個体果実のエチンン生成量 が $0.2 \mathrm{nmol}^{-1} \mathrm{~g}^{-1} \mathrm{~h}^{-1}\left(4.8 \mu 1 \mathrm{~kg}^{-1} \mathrm{~h}^{-1}\right)$ までは注ぼ一定值 $\left(0.6 \mathrm{nmolg}^{-1}\right.$ と $\left.2 \mathrm{nmolg}^{-1}\right)$ であったが果実のエチレン 生成量が上記の值を越すにつれ共に平行して増大した. この時 MACC の含量は ACC の含量より 5 倍以上高か った. エチレン生成酵素 (EFE) の活性は果実のエチレ ソ生成量と密接な相関を有し, 果実のエチレン生成量の 増大と比例して著しく増加した.これらの結果は前報で 述ベたキウイフルーツにおけるエチレン生合成はメチオ ニンーACC 経路を通るといら結論を支持するものと思わ れる. 